\title{
Historical review on the type locality of Knodus victoriae (Steindachner 1907) (Teleostei: Characidae) and Loricaria parnahybae Steindachner 1907 (Teleostei: Loricariidae)
}

\author{
Rayane Gonçalves Aguiar ${ }^{1,2,3}$, Erick Cristofore Guimarães ${ }^{2(1)}$, Luis Fernando Carvalho-Costa ${ }^{2}$ \& Felipe \\ Polivanov Ottoni ${ }^{1,3 * \text { (1) }}$ \\ ${ }^{1}$ Universidade Federal do Maranhão, Programa de Pós-Graduação em Biodiversidade e Conservação, Av. dos \\ Portugueses 1966, Cidade Universitária Dom Delgado, CEP 65080-805, São Luís, MA, Brasil. \\ ${ }^{2}$ Universidade Federal do Maranhão, Departamento de Biologia, Laboratório de Genética e Biologia \\ Molecular, Av. dos Portugueses 1966, Cidade Universitária do Bacanga, CEP 65080-805, São Luís, MA, Brasil. \\ ${ }^{3}$ Universidade Federal do Maranhão, Centro de Ciências Agrárias e Ambientais (CCAA), Laboratório \\ de Sistemática e Ecologia de Organismos Aquáticos, BR-222, KM 04, S/N, Boa Vista, CEP 65500-000, \\ Chapadinha, MA, Brasil. \\ *Corresponding author: fpottoni@gmail.com
}

AGUIAR, R.G., GUIMARÃES, E.C., CARVALHO-COSTA, L.F., OTTONI, F.P. Historical review on the type locality of Knodus victoriae (Steindachner 1907) (Teleostei: Characidae) and Loricaria parnahybae Steindachner 1907 (Teleostei: Loricariidae). Biota Neotropica 21(4): e20211226. https://doi.org/10.1590/1676-0611-BN-2021-1226

\begin{abstract}
Based on the information and evidence on the zoological expedition led by the senior Austrian zoologist Franz Steindachner in 1903, the examination of original species descriptions using material collected in this expedition, the scientific literature on this expedition, examination of specimens of Knodus victoriae, and the consultation of State decrees modifying the name of localities and municipalities, we propose herein updated and accurate type localities for Knodus victoriae and Loricaria parnahybae. The accurate type locality for both species is at the mouth of a stream that flows into the Parnaiba River, Alto Parnaíba municipality in the State of Maranhão, upper Parnaiba River basin, northeastern Brazil. This update in the type locality aims to avoid doubts and confusion that hinder biogeographic and taxonomic studies.
\end{abstract}

Keywords: Characiformes; Santa Filomena; Siluriformes; Taxonomy; Vienna Imperial Academy of Sciences.

\section{Revisão histórica sobre a localidade tipo de Knodus victoriae (Steindachner 1907) (Teleostei: Characidae) e Loricaria parnahybae Steindachner 1907 (Teleostei: Loricariidae)}

\footnotetext{
Resumo: Com base em informações e evidências da expedição zoológica liderada pelo zoólogo sênior austríaco Franz Steindachner em 1903, exame das descrições originais das espécies que utilizaram material coletado nessa expedição, literatura científica sobre essa expedição, exame de exemplares de Knodus victoriae, e consulta a decretos estaduais que modificaram o nome de localidades e municípios, nós propomos a atualização com acurácia das localidades tipos de Knodus victoriae e Loricaria parnahybae. A localidade tipo acurada para ambas as espécies é na foz de um riacho que desagua no rio Parnaíba, no município de Alto Parnaíba no Estado do Maranhão, bacia do alto rio Parnaíba, nordeste do Brasil. Esta atualização na localidade tipo visa evitar dúvidas e confusões que podem atrapalhar estudos biogeográficos e taxonômicos.
}

Palavras-chave: Academia Imperial de Ciências de Viena; Characiformes; Santa Filomena; Siluriformes; Taxonomia. 
Aguiar, R.G. et al.

\section{Introduction}

In 1903, the Vienna Imperial Academy of Sciences organized an important expedition to Brazil, led by the Austrian zoologist Franz Steindachner (1834-1919) (Vanzolini 1992, Böhme 1996), aiming to explore a vast area in the northeast and northern regions of the country (Mello-Leitão 1941, Böhme 1996). On January 2nd, 1903, they left Genoa (Italy) and arrived at the port of Recife (State of Pernambuco), northeastern Brazil, on February 16th of the same year, where the expedition started (Vanzolini 1992, Böhme 1996). Steindachner and his team traveled for about eight months through different localities (Vanzolini 1992, Böhme 1996). On June 11th, 1903, the expedition arrived at Santa Filomena (State of Piauí) (Vanzolini 1992), in the upper Parnaiba River, at the border between the States of Piauí and Maranhão. Soon after the arrival, Steindachner received fishes from the Parnaiba River, and from a neighboring tributary of Parnaíba, the Medonho River (Böhme 1996), whose mouth is located near the ancient village of Vitória do Alto Parnaíba, currently Alto Parnaíba municipality (State of Maranhão) according to the State of Maranhão decree-law number 820 (IBGE 2017). They left Santa Filomena and its surrounding areas on July 20-21th, 1903 after spending about 20 days collecting and receiving fish specimens from this region and vicinities (Steindachner 1907a, b, c, Vanzolini 1992, Böhme 1996). The Alto Parnaíba municipality (State of Maranhão) is about $2 \mathrm{~km}$ away in a straight line from Santa Filomena municipality (State of Piauí), both located at the border between the states on the banks of the Parnaiba River, which separates them (Figure 1).

The expedition resulted in the description of new fish species from the Parnaiba River basin (e.g., Steindachner 1906, Steindachner 1907a, b, c), such as: Corydoras julii Steindachner 1906, Corydoras treitlii Steindachner 1906, Corydoras raimundi Steindachner 1907 [Aspidoras raimundi], Loricaria parnahybae Steindachner 1907, Prochilodus lacustris Steindachner 1907, Tetragonopterus sanctaefilomenae Steindachner 1907 [Moenkhausia sanctaefilomenae], Tetragonopterus victoriae Steindachner 1907 [Knodus victoriae] and Xenocara damasceni Steindachner 1907 [Ancistrus damasceni]. Some of these species have confusing, inaccurate and outdated type localities, with municipality's names no longer corresponding to current names. Therefore, we aimed to provide an accurate and updated type locality for two species described by Steindachner - Knodus victoriae and Loricaria parnahybae - whose type material was collected during his 1903 expedition in Brazil, but remain with inaccurate and outdated type localities.

\section{Methods}

Information on the 1903 Steindachner's expedition and type localities, including their updated names, were based on the following literature: Steindachner (1906), Steindachner (1907a, b, c), Mello-

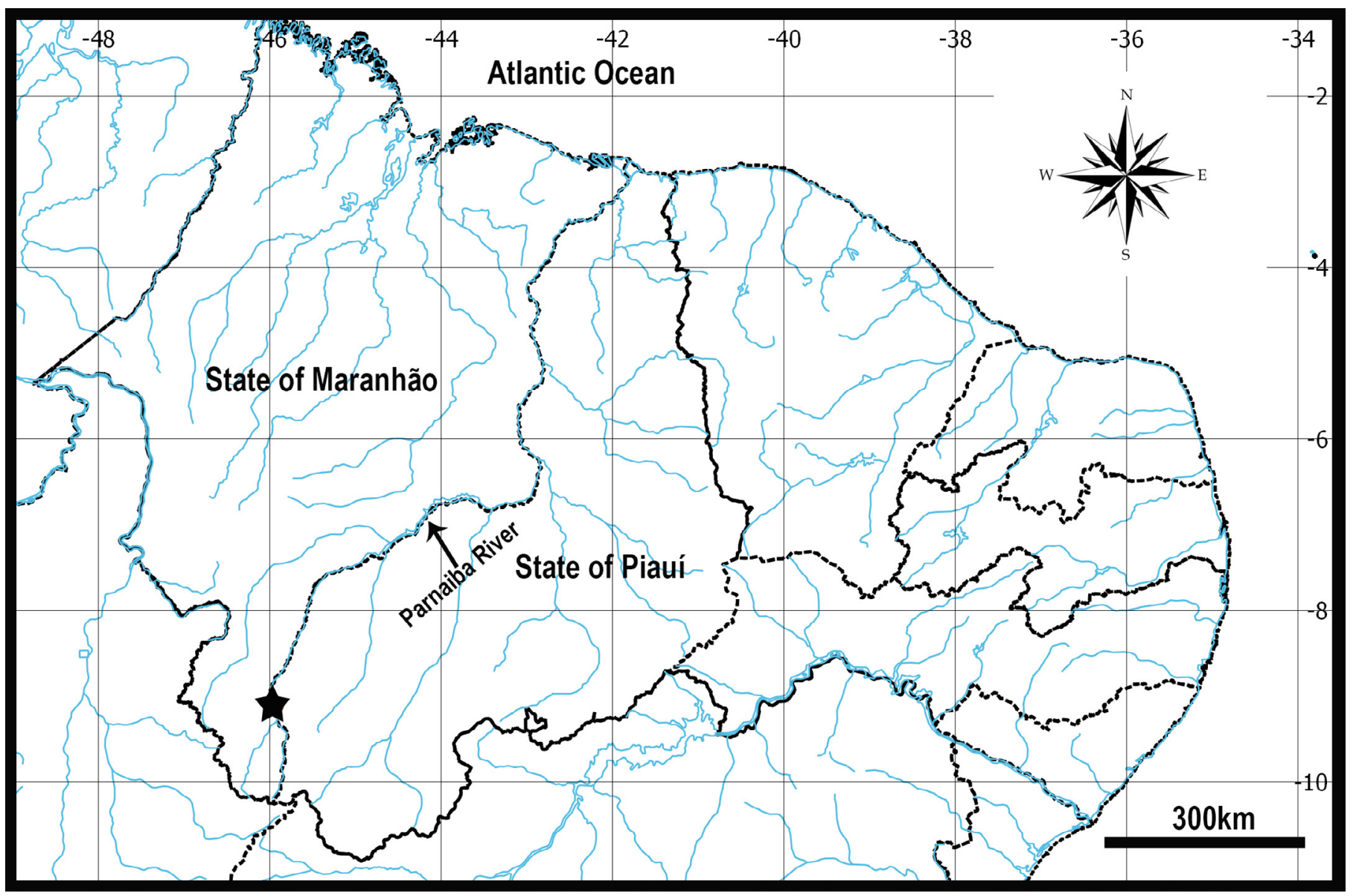

Figure 1. Map showing the updated and accurate type locality of Knodus victoriae and Loricaria parnahybae. Black star corresponds to the municipalities of Alto Parnaíba (State of Maranhão) and Santa Filomena (State of Piauí), about $2 \mathrm{~km}$ away, both located at the border between these states on the banks of the Parnaiba River. 
Leitão (1941), Weitzman et al. (1964), Nijssen and Isbrücker (1976, 1980), Vanzolini (1992), Böhme (1996), Reis et al. (2003), Buckup et al. (2007), IBGE (2017), and Fricke et al. (2021). Vanzolini (1992) provided detailed information on the expedition itinerary, maps and diary, allowing us to have access to these information. In addition, ECG conducted a collection expedition in the Alto Parnaíba municipality (State of Maranhão), depositing specimens of Knodus victoriae collected at this locality in the Coleção Ictiológica do Centro de Ciências Agrárias e Ambientais of the Universidade Federal do Maranhão (CICCAA).

\section{Results and Discussion}

Original type localities of the two species are described in Steindachner (1907a, 1907b). Both species were described for the Parnaiba River basin, near the ancient village of Vitória do Alto Parnaíba[ now Alto Parnaíba municipality (State of Maranhão)], according to the following excerpts from Steindachner (1907a, 1907b) translated from German to English:

a) Tetragonopterus victoriae Steindachner [F.] 1907a:83 [currently Knodus victoriae]

Original excerpt: "Diese art, welche häufig in einem kleinen Bache nächst seiner Mündung in den Parnahyba bei dem Städtchen Victoria vorkommt... "(Steindachner 1907a: 84).

Translated to English: "This species, which is very common in a small stream near to its mouth in the Parnahyba river, near the town of Victoria ...."

b) Loricaria parnahybae Steindachner [F.] 1907b:153

Original excerpt: “...aus dem Rio Parnahyba an der Mündung eines Baches bei dem Stadtchen Victoria. “ (Steindachner 1907b:154)

Translated to English: "...from the Rio Parnahyba at the mouth of a stream near the town of Victoria."

For several years, some authors have been literally keeping these type localities according to their original description (e.g., Reis et al. 2003), either reporting them to the State of Maranhão or making simple or wrong interpretations (e.g., Eigenmann 1918, Buckup et al. 2007, Fricke et al. 2021, Scharpf \& Kenneth 2021); however, none of them updated the name of the locality "Victoria", currently Alto Parnaíba municipality (see Introduction). Interpretations keeping the original name of the localities may suggest that it is at some point at the mouth of the Parnaiba River. The location "Städtchen Victoria (town of Victoria) " [village of Vitória do Alto Parnaíba, currently Alto Parnaíba municipality in the State of Maranhão (IBGE 2017)], is actually located in the upper Parnaiba River basin section, and not in its lower portion (near the mouth).

Therefore, the most accurate type locality of both Knodus victoriae and Loricaria parnahybae is at the mouth of a stream that flows into the Parnaiba River, Alto Parnaíba municipality in the State of Maranhão, upper Parnaiba River basin, northeastern Brazil. This region encompasses bordering headwaters and river portions between the upper Parnaiba and São Francisco River basins. This updated type locality can change the biogeographic interpretations for these two species, and it may also be important for future DNA-based taxonomic or systematic studies in case specimens need to be collected.

Previous studies also corroborate our conclusions. For instance, Weitzman et al. (1964) and Nijssen and Isbrücker (1976) also concluded that the type locality of Aspidoras raimundi, originally addressed to the location "....in dem Bächchen, welches bei Victoria in den Rio Parnahyba mündet" (Steindachner 1907c:83) (translated to English: "in the stream, which ends near Victoria in the Rio Parnahyba"), currently corresponds to the mouth of a stream flowing to the Parnaiba River at Alto Parnaiba, State of Maranhão, Brazil. Nijssen and Isbrücker (1980) also reported a similar case with Corydoras julii and Corydoras treitlii that also had their type localities originally addressed to the same location in the "Rio Parnahyba" at "Victoria", but the type localities of both species were updated to: Brazil-Maranhão, creek into Rio Parnaiba near Alto Parnaíba (=Victoria) $\left(09^{\circ} 08^{\prime} \mathrm{S} ; 45^{\circ} 56^{\prime} \mathrm{W}\right)$. However, none of these authors explained in detail how they obtained their conclusions on the updated name of the locality.

Misinterpretations of type localities based on historical works are recurrent. Several species with old descriptions have inaccurate and/ or confusing type localities (e.g., Steindachner 1907a, b, c, Lucena and Lucena 1990), which are often literally translated to English — changing the original context (e.g., the type locality of Knodus victoriae, Fricke et al. 2021). However, erroneous designation or wrong interpretations of type localities hinders biogeographical and taxonomic studies as accurate type localities are crucial for these type of studies (Ottoni et al. 2020). Therefore, several studies have been correcting and updating type localities more accurately to avoid taxonomic and biogeographic confusions (e.g., Lima and Géry 2001, Lucinda and Lucena 2012, Koerber 2016, Ottoni et al. 2020).

Therefore, considering: 1) that there is no municipality with the name "Victoria" in the lower Parnaiba River region; 2) the translation of the Steindachner's original descriptions; 3) specimens of Knodus victoriae collected by ECG (in 2021) in the Alto Parnaíba municipality (State of Maranhão) fit the original description of the species, and the features of its type material; and 4) the State decree modifying the name of localities and municipalities [the State of Maranhão decreelaw number 820 (IBGE 2017)]; all of these evidences corroborate the updating of the type locality of Knodus victoriae and Loricaria parnahybae to the mouth of a stream that flows into the Parnaiba River, Alto Parnaíba municipality in the State of Maranhão, upper Parnaiba River basin, northeastern Brazil (Figure 1).

\section{Acknowledgments}

We thank Ingo Schindler for providing some useful literature and translating the original description of Knodus victoriae from German to English; CAPES (Coordenação de Aperfeiçoamento de pessoal de nível Superior - Finance Code 001) for providing the scholarship to RGA under the process 88882.445737/2019-01; and FAPEMA (Fundação de Amparo à Pesquisa e Desenvolvimento Científico e Tecnológico do Maranhão) for providing financial support for this study.

\section{Author Contributions}

Rayane Gonçalves Aguiar: Concept and design of the study; Contribution to data collection; Contribution to data analysis and interpretation; Contribution to manuscript preparation; Contribution to critical revision, adding intellectual content.

Erick Cristofore Guimarães: Concept and design of the study; Contribution to data collection; Contribution to data analysis and interpretation; Contribution to manuscript preparation; Contribution 
to critical revision, adding intellectual content; collection expedition in the Alto Parnaíba municipality (State of Maranhão).

Luis Fernando Carvalho-Costa: Concept and design of the study; Contribution to data collection; Contribution to data analysis and interpretation; Contribution to manuscript preparation; Contribution to critical revision, adding intellectual content; English language review.

Felipe Polivanov Ottoni: Concept and design of the study; Contribution to data collection; Contribution to data analysis and interpretation; Contribution to manuscript preparation; Contribution to critical revision, adding intellectual content.

\section{Conflicts of Interest}

There is no conflict of interest.

\section{References}

Böhme, K. 1996. Briefe Franz Steindachners von der brasilien-expedition 1903. Annalen des Naturhistorisches Museums in Wien, 98:545-568.

Buckup, P.A., Menezes, N.A., Ghazz, M. S. 2007. Catálogo das espécies de peixes de água doce do Brasil. Museu Nacional, Rio de Janeiro, 195pp.

Eigenmann, C. 1918. The American Characidae. Memoirs of the Museum of Comparative Zoology, 43: 103-208. https://www.biodiversitylibrary.org/ page $/ 4372773$

Fricke, R., Eschmeyer, W. N., Van der Laan, R. (eds). 2021. ESCHMEYER'S CATALOG OF FISHES: GENERA, SPECIES, REFERENCES. (http:// researcharchive.calacademy.org/research/ichthyology/catalog/fishcatmain. asp). Electronic version accessed 18/01/2021.

Koerber, S. 2016. The type locality of Laetacara dorsigera (Heckel, 1840) and other species collected in 'Villa Maria' is today known as the city of Cáceres, Brazil. Historia Natural, 6: 141-143.

Lima, F. C. T., Géry, J. 2001. Correction of the type locality of Hyphessobrycon stegemanni Géry and Knodus savannensis Géry (Teleostei: Characiformes: Characidae). Comunicações do Museu de Ciências e Tecnologia da PUCRS, Série Zoologia, Porto Alegre, 14: 95-97.

Lucena, Z. D., Lucena, C. D. 1990. Sobre a localidade-tipo das espécies de peixes descritas por Steindachner (1907). Comunicações do Museu de Ciências e Tecnologia da PUCRS, Série Zoologia, Porto Alegre, 3: 99-101.

Lucinda, P. H. F., Lucena, C. A. S. 2012. The type locality and type series of Potamophylax pygmaeus Myers \& Carvalho, 1955 (Teleostei: Poeciliidae). Ichthyological Exploration of Freshwaters, 23: 56.

Mello-Leitão, C. F. 1941. História das Expedições Científicas no Brasil. Companhia Ed. Nacional, 349pp. http://bdor.sibi.ufrj.br/handle/doc/293
IBGE- Instituto Brasileiro de Geografia e Estatística. 2017. História: Alto Parnaíba-MA. Retrieved 18 January 2021. https://cidades.ibge.gov.br/brasil/ $\mathrm{ma} /$ alto-parnaiba/historico

Nijssen, H. Isbrücker, I. J. H. 1976. The South American plated catfish genus Corydoras R. von Ihering, 1907, with descriptions of nine new species from Brazil (Pisces, Siluriformes, Callichthyidae). Bijdr. Dierk., 46:107-131.

Nijssen, H., Isbrücker, I. J. H. 1980. A review of the genus Corydoras Lacépède, 1803(Pisces, Siluriformes, Callichthyidae). Bijdragen tot de Dierkunde, 50:190-220.

Ottoni, F. P., Katz, A. M., Bragança, P. H. N. 2020. Correction of the type locality of Australoheros ipatinguensis (Teleostei: Cichlidae). Ichthyological Exploration of Freshwaters, 1128:1-3. http://doi.org/10.23788/IEF-1128

Reis, R. E., Kullander, S. O., Ferraris, C. J. (eds). 2003. Check list of the freshwater fishes of South and Central America. CLOFFSCA. EDIPUCRS, Porto Alegre. 2003: i-xi +1-729.

Scharpf, C., Lazara, K. J. 2021. "Subfamily STEVARDIINAE". The ETYFish Project Fish Name Etymology Database. (https://www.etyfish.org/). Retrieved 18 January 2021.

Steindachner, F. 1906. Zwei neue Corydoras-Arten aus dem Parnahyba- und Parahimflusse im Staate Piauhy. Anzeiger der Kaiserlichen Akademie der Wissenschaften, Mathematisch-Naturwissenschaftlichen Classe. 43:478-480.

Steindachner, F. 1907a. Über eine neue Psilichthys-Art, Ps. cameroni aus dem Flusse Cubataõ im Staate S. Catharina, Brasilien. Anzeiger der Kaiserlichen Akademie der Wissenschaften, Wien, Mathematisch-Naturwissenschaftliche Klasse v. 44(6): 82-85. https://www.biodiversitylibrary.org/page/27983666

Steindachner, F. 1907b. Über zwei neue Arten von Süßwasserfischen aus dem Stromgebiete des Parnahyba. Anzeiger der Kaiserlichen Akademie der Wissenschaften, Wien, Mathematisch-Naturwissenschaftliche Klasse. 44(10):152-155. https://www.biodiversitylibrary.org/page/6348273

Steindachner, F. 1907c. Über eine neue Coridoras-Art aus dem Rio Preto, einem sekundären Nebenflusse des Rio San Francisco, undeine Xenocara-Art aus dem Parnahyba bei Victoria und Sa. Filomena. Anzeiger der Kaiserlichen Akademie der Wissenschaften, Wien, Mathematisch-Naturwissenschaftliche Klasse. 44(17):290-293. https://www.biodiversitylibrary.org/page/6348408

Vanzolini, P. E. 1992. Itinerary of the Austrian expedition to northeastern Brazil in 1903. Anais da Academia Brasileira de Ciências. 64(4):397-405.

Weitzman, S. H. 1964. One new species and two redescriptions of catfishes of the South American callichthyid genus Corydoras. Proceedings of the United States National Museum, 116:115-126. https://doi.org/10.5479/ si.00963801.116-3498.115

Received: $12 / 04 / 2021$

Revised: 22/06/2021

Accepted: 07/07/2021

Published online: 30/07/2021 